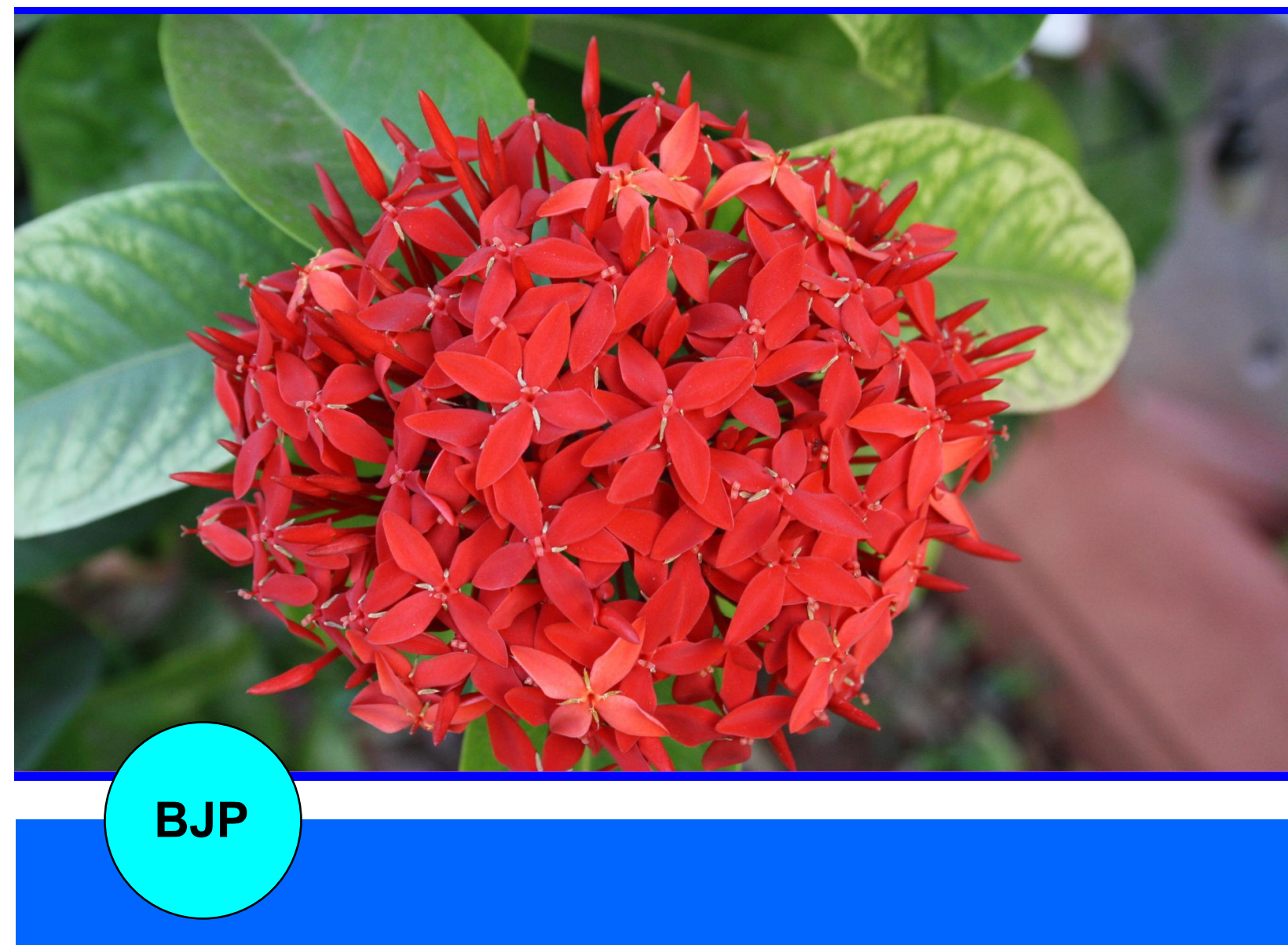

Bangladesh Journal of Pharmacology

Research Article

In vitro free radical scavenging activity of Ixora coccinea $L$ 


\title{
In vitro free radical scavenging activity of Ixora coccinea $L$
}

\author{
Moni Rani Saha, Md. Ashraful Alam, Raushanara Akter and Rumana Jahangir \\ Phytochemistry and Pharmacology Laboratory, Department of Pharmacy, Stamford University Bangladesh, Dhaka \\ 1217, Bangladesh.
}

\begin{tabular}{|c|c|}
\hline \multicolumn{2}{|l|}{ Article Info } \\
\hline Received: & 14 May 2008 \\
\hline Accepted: & 8 July 2008 \\
\hline Available Online: & 15 July 2008 \\
\hline \multicolumn{2}{|c|}{ DOI: 10.3329/bjp.v3i2.838 } \\
\hline \multicolumn{2}{|c|}{$\begin{array}{l}\text { Cite this article: } \\
\text { Saha MR, Alam MA, Akter R, Jahang- } \\
\text { ir R. In vitro free radical scavenging } \\
\text { activity of Ixora coccinea L. Bangladesh } \\
\text { J Pharmacol. 2008; 3: 90-96. }\end{array}$} \\
\hline
\end{tabular}

\begin{abstract}
Antioxidant activity of the methanol extract of Ixora coccinea L. was determined by DPPH free radical scavenging assay, reducing power and total antioxidant capacity using phosphomolybdenum method. Preliminary phytochemical screening revealed that the extract of the flower of I. coccinea possesses flavonoids, steroids and tannin materials. The extract showed significant activities in all antioxidant assays compared to the standard antioxidant in a dose-dependent manner and remarkable activities to scavenge reactive oxygen species (ROS) may be attributed to the high amount of hydrophilic phenolics. In DPPH radical scavenging assay the $\mathrm{IC}_{50}$ value of the extract was found to be $100.5 \mu \mathrm{g} / \mathrm{mL}$ while ascorbic acid had the $\mathrm{IC}_{50}$ value $58.9 \mu \mathrm{g} / \mathrm{mL}$. Moreover, I. coccinea extract showed strong reducing power and total antioxidant capacity.
\end{abstract}

\section{Introduction}

In living systems, free radicals are generated as part of the body's normal metabolic process, and the free radical chain reactions are usually produced in the mitochondrial respiratory chain, liver mixed function oxidases, through xanthine oxidase activity, atmospheric pollutants and from transitional metal catalysts, drugs and xenobiotics. In addition, chemical mobilization of fat stores under various conditions such as lactation, exercise, fever, infection and even fasting, can result in increased radical activity and damage.

Free radicals or oxidative injury now appears the funda -mental mechanism underlying a number of human neurologic and other disorders. For instance in diabetes, increased oxidative stress which co-exist with reduction in the antioxidant status has been postulated. Oxygen free radical can initiate peroxidation of lipids, which in turn stimulates glycation of protein, inactivation of enzymes and alteration in the structure and function of collagen basement and other membranes, and play a role in the long-term complication of diabetes (Sabu and Kuttan, 2002; Boynes, 1991; Collier et al., 1990). Although synthetic antioxidants such as butylated hydroxytoluene, butylated hydroxyanisole, and tertbutylhydroquinone have been commonly used as antioxidants in foods for years, their safety has long been questioned (Branen, 1975; Ito et at., 1983). This has led to an increased interest in natural antioxidants (Lim et al., 2002; Kayano et al., 2002; Gyamfi and Aniya, 2002; Braca et al., 2002).

Spices and herbs are recognized as sources of natural anti-oxidants that can protect from oxidative stress and thus play an important role in the chemoprevention of diseases that has their etiology and pathophysiology in reactive oxygen species. The medicinal properties of 
folk plants are mainly attributed to the presence of flavonoids, but may also be influenced by other organic and inorganic compounds such as coumarins, phenolic acids and antioxidant micro-nutrients, e.g., $\mathrm{Cu}, \mathrm{Mn}, \mathrm{Zn}$ (Repetto and Llesuy, 2002). Ixora coccinea L. belongs to the family Rubiacae, is a common flowering shrub native to Asia including Bangladesh, Southern India, and Sri Lanka (Ghani, 2003). Leaves are given in diarrhea (Ghani, 2003). Flowers are used in the treatment of dysentery, leucorrhoea, dysmenorrhoea, hemoptysis and catarrhal bronchitis (Ghani, 2003). Roots possess stomachic and sedative properties.

I. coccinea flowers showed chemoprotective effects on cyclophosphamide-induced toxicity by increasing the life span of treated mice (Latha and Panikkar, 1999). Ether and methanol extracts of I. coccinea dry leaves have antimicrobial activity (Annapurna et al., 2003). Flowers have cytotoxic and antitumor activity in mice (Latha and Panikkar, 1998). Aqueous leaf extract of $I$. coccinea leaves showed antinociceptive activity in mice (Ratnasooriya et al., 2005a,b). The extract of I. coccinea flowers contains triterpenoid and ursolic acid (Latha and Panikkar, 1999). The air-dried flowers of I. coccinea afforded two new cyclo-artenol esters, lupeol fatty ester, lupeol, ursolic acid, oleanolic acid, and sitosterol. The structures were elucidated by extensive 1D and 2D NMR spectroscopy and MS (Ragasa et al., 2004).

A review of literature did not reveal any information on the antioxidant study of this plant. As a part of our ongoing investigations about natural anti-oxidants from local medicinal plants of Bangladesh (Alam et al., 2008a; Alam et al., 2008b), in this paper, we have reported the antioxidant activity of the flowers of $I$. coccinea. The evaluation of antioxidant power was performed in vitro by the DPPH (1, 1-diphenyl, 2picrylhydrazyl), reducing power and total antioxidant capacity assays.

\section{Materials and Methods}

\section{Chemicals}

DPPH, trichloroacetic acid and ferric chloride were obtained from Sigma Chemical Co. USA. Ascorbic acid was obtained from SD Fine Chem. Ltd., Biosar, India. Sodium nitroprusside was obtained from Ranbaxy Lab., Mohali, India. Potassium ferricyanide was obtained from May and Backer, Dagenham, UK. Ammonium molybdate was purchased from Merck, Germany.

\section{Plant material}

Flowers of I. coccinea were collected from Gazipur, Bangladesh in June 2007, and identified by Prof. Abdul Ghani (Stamford University, Dhaka, Bangladesh); a voucher specimen (SU-MAA-2007-7) for this collection has been retained in the Pharmacognosy Laboratory, Stamford University, Dhaka, Bangladesh.

\section{Extraction}

The shade-dried flowers were coarsely powdered and extracted with mixture of methanol: water (7:3 ratio) by a soxhlet apparatus at $45^{\circ} \mathrm{C}$. The solvent was completely removed by rotary evaporator and obtained greenish gummy exudates. This crude extract was used for further investigation for potential antioxidant properties.

\section{Phytochemical screening}

The freshly prepared extract of $I$. coccinea was qualitatively tested for the presence of chemical constituents. Phytochemical screening of the extract was performed using the following reagents and chemicals: Alkaloids with Dragendorffs reagent, flavonoids with the use of $\mathrm{Mg}$ and $\mathrm{HCl}$; tannins with ferric chloride and potassium dichromate solutions and saponins with ability to produce suds. Gum was tested using Molish reagents and concentrated sulfuric acid. These were identified by characteristic color changes using standard procedures (Trease and Evans, 1983).

\section{DPPH radical scavenging activity}

The free radical scavenging capacity of the extracts was determined using DPPH (Hasan et al., 2006). DPPH solution $(0.004 \% \mathrm{w} / \mathrm{v})$ was prepared in $95 \%$ methanol. Methanol extract of $I$. coccinea was mixed with $95 \%$ methanol to prepare the stock solution $(5 \mathrm{mg} / \mathrm{mL})$. Freshly prepared DPPH solution $(0.004 \% \mathrm{w} / \mathrm{v})$ was taken in test tubes and I. coccinea extracts was added followed by serial dilutions ( 1 to $500 \mu \mathrm{g})$ to every test tube so that the final volume was $3 \mathrm{~mL}$ and after 10 min, the absorbance was read at $515 \mathrm{~nm}$ using a spectrophotometer (HACH 4000 DU UV-visible spectrophotometer). Ascorbic acid was used as a reference standard and dissolved in distilled water to make the stock solution with the same concentration (5 $\mathrm{mg} / \mathrm{mL}$ ). Control sample was prepared containing the same volume without any extract and reference ascorbic acid. 95\% methanol was used as blank. \% scavenging of the DPPH free radical was measured using the following equation: Absorbance of the control minus absorbance of the test sample divided by absorbance of the control multiplied by 100 .

The inhibition curve was plotted for duplicate experiments and represented as \% of mean inhibition \pm standard deviation. IC $_{50}$ values were obtained by probit analysis (Viturro et al., 1999).

\section{Reducing power}

The reducing power of $I$. coccinea was determined according to the method previously described (Oyaizu, 1986). Different concentrations of I. coccinea extract (100 
$-1,000 \mu \mathrm{g})$ in $1 \mathrm{~mL}$ of distilled water was mixed with phosphate buffer (2.5 mL, $0.2 \mathrm{M}, \mathrm{pH}$ 6.6) and potassium ferricyanide $\left[\mathrm{K}_{3} \mathrm{Fe}(\mathrm{CN})_{6}\right](2.5 \mathrm{~mL}, 1 \%)$. The mixture was incubated at $50^{\circ} \mathrm{C}$ for $20 \mathrm{~min}$. A portion $(2.5 \mathrm{~mL})$ of trichloroacetic acid $(10 \%)$ was added to the mixture, which was then centrifuged at 3,000 rpm for $10 \mathrm{~min}$. The upper layer of the solution $(2.5 \mathrm{~mL})$ was mixed with distilled water $(2.5 \mathrm{~mL})$ and ferric chloride $(0.5 \mathrm{~mL} .0 .1 \%)$ and the absorbance was measured at 700 $\mathrm{nm}$. Increased absorbance of the reaction mixture indicated increased reducing power. Ascorbic acid was used as a reference standard. Phosphate buffer ( $\mathrm{pH}$ 6.6) was used as blank solution. The absorbance of the final reaction mixture of two parallel experiments were taken was expressed as mean \pm standard deviation.

\section{Determination of total antioxidant capacity}

The anti-oxidant activity of the extracts of I. coccinea was evaluated by the phosphomolybdenum method according to the procedure of Prieto et al. (1999). The assay is based on the reduction of Mo (VI)-Mo (V) by the extract and subsequent formation of a green phosphate/Mo (V) complex at acid pH. $0.3 \mathrm{~mL}$ extract was combined with $3 \mathrm{~mL}$ of reagent solution $(0.6 \mathrm{M}$ sulfuric acid, $28 \mathrm{mM}$ sodium phosphate and $4 \mathrm{mM}$ ammonium molybdate). The tubes containing the reaction solution were incubated at $95^{\circ} \mathrm{C}$ for $90 \mathrm{~min}$. Then the absorbance of the solution was measured at $695 \mathrm{~nm}$ using spectrophotometer against blank after cooling to room temperature. Methanol $(0.3 \mathrm{~mL})$ in the place of extract was used as the blank. The anti-oxidant activity is expressed as the number of equivalents of ascorbic acid.

\section{Results and Discussion}

Preliminary phytochemical screening of the extract of $I$. coccinea revealed the presence of various bioactive components of which flavonoids and tannins were the most prominent and the result of phytochemical test has been summarized in the Table I. Phenolic compounds and flavonoids have been reported to be associated with antioxidative action in biological systems, acting as scavengers of singlet oxygen and free radicals (Rice-Evans et al., 1997; Jorgensen et al., 1999). Literature reviews about the plant also confirm the presence of terpinoids group. Many naturally occurring triterpinoids exhibited a good antiinflammatory activity have been isolated from various plants (Fernandez et al., 2001; Ismaili et al., 2002). Pentacyclic triterpinoids have a wide spectrum of biological activities and some of them may be useful in medicine. There is growing interest in natural triterpinoids caused as much by the scientific aspects extraction and structural analysis of these compounds, as by the fact of their wide spectrum of biological

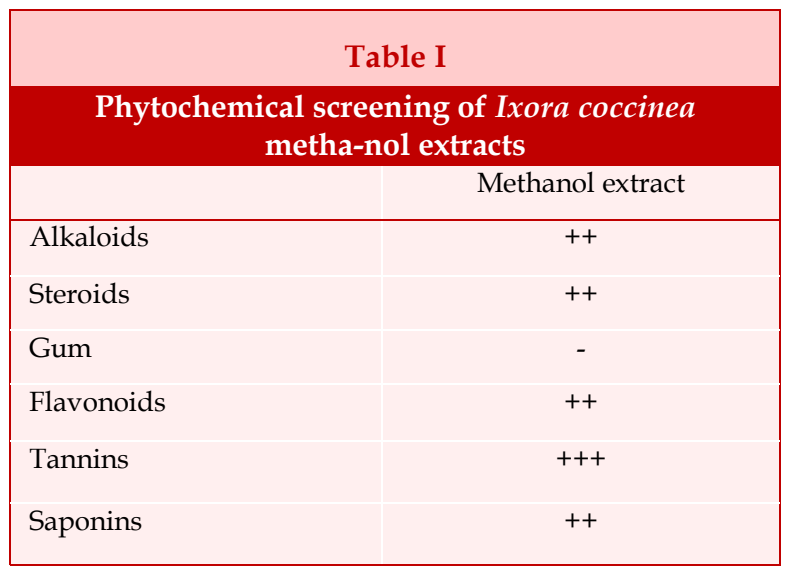

activities, they are bactericidal, fungicidal, antiviral, cytotoxic, analgesic, anti-inflammatory, anti-cancer and antiallergic (Patocka, 2003).

In this present study the antioxidant activity of the methanol extracts of the flowers of I. coccinea were investigated by using DPPH scavenging assay, reducing power of the extract and by determining total antioxidant capacity of the extract. All the three methods have proven the effectiveness of the methanol extract compared to the reference standard antioxidant ascorbic acid.

The DPPH antioxidant assay is based on the ability of $\mathrm{DPPH}$, a stable free radical, to decolorize in the presence of antioxidants. The DPPH radical contains an odd electron, which is responsible for the absorbance at $517 \mathrm{~nm}$ and also for visible deep purple color. When DPPH accepts an electron donated by an anti-oxidant compound, the DPPH is decolorized which can be quantitatively measured from the changes in absorbance. Comparison of the antioxidant activity of the extract and ascorbic acid is shown in Figure 1. The methanol extract of $I$. coccinea exhibited a significant dose-dependent inhibition of DPPH activity, with a $50 \%$ inhibition $\left(\mathrm{IC}_{50}\right)$ at a concentration of $100.5 \mu \mathrm{g} / \mathrm{mL}$. The $\mathrm{IC}_{50}$ value of the extract was found to be comparable to reference standard ascorbic acid $\left(\mathrm{IC}_{50}\right.$ $58.9 \mu \mathrm{g} / \mathrm{mL}$ ).

The reducing ability of a compound generally depends on the presence of reductants (Duh, 1999), which have been exhibited anti-oxidative potential by breaking the free radical chain, donating a hydrogen atom (Gordon, 1990). The presence of reductants (i.e. anti-oxidants) in I. coccinea extract causes the reduction of the $\mathrm{Fe}^{3+}$ / ferricyanide complex to the ferrous form. Therefore, the $\mathrm{Fe}^{2+}$ can be monitored by measuring the formation of Perl's Prussian blue at $700 \mathrm{~nm}$. Figure 2 shows the reductive capabilities of the plant extract compared to ascorbic acid. The reducing power of extract of $I$. coccinea was very potent and the power of the extract was increased with quantity of sample. 


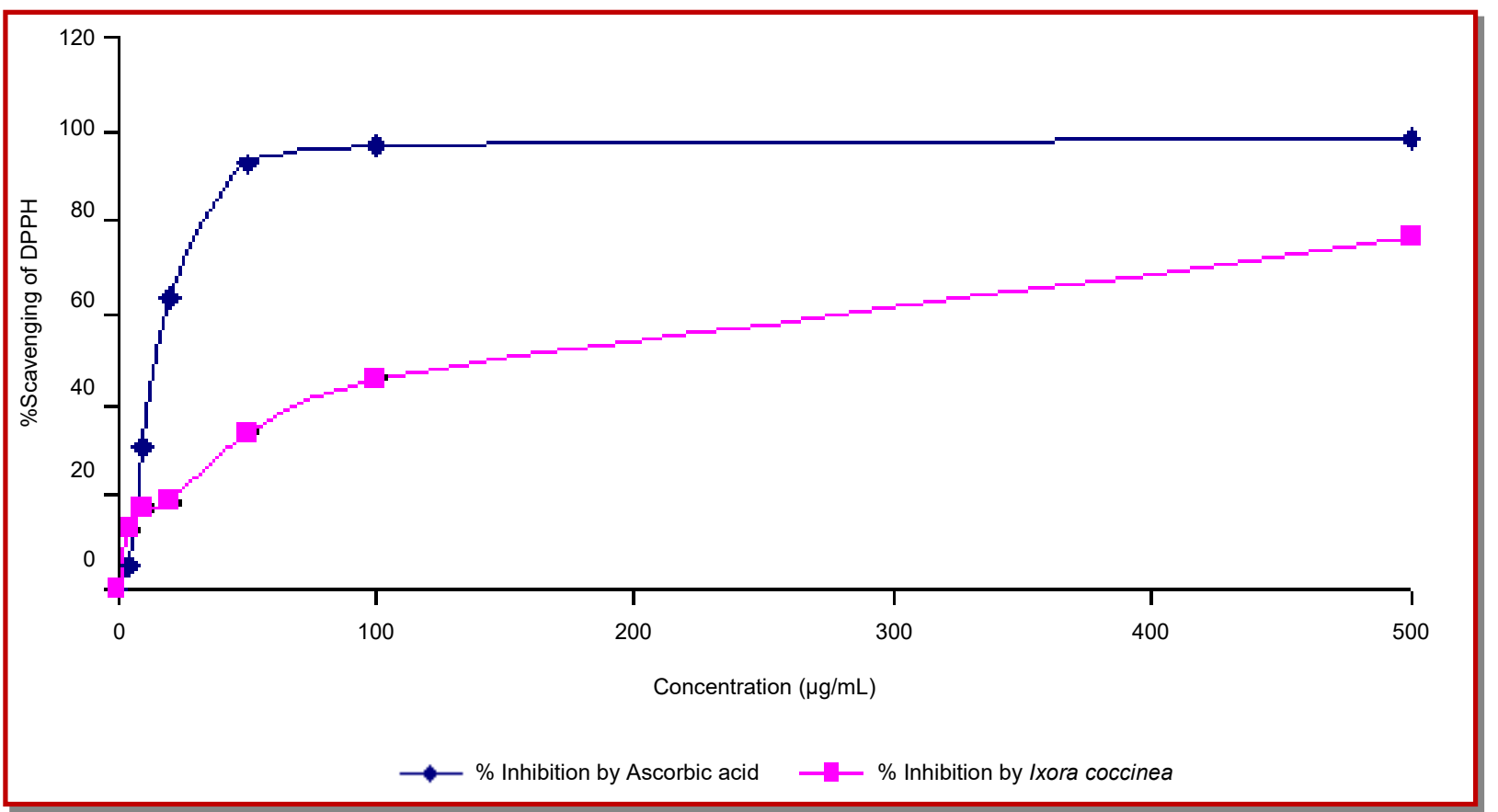

Figure 1: DPPH radical scavenging activity of ascorbic acid and methanol extract of Ixora coccinea flowers. Values are the average of duplicate experiments and represented as mean \pm standard deviation

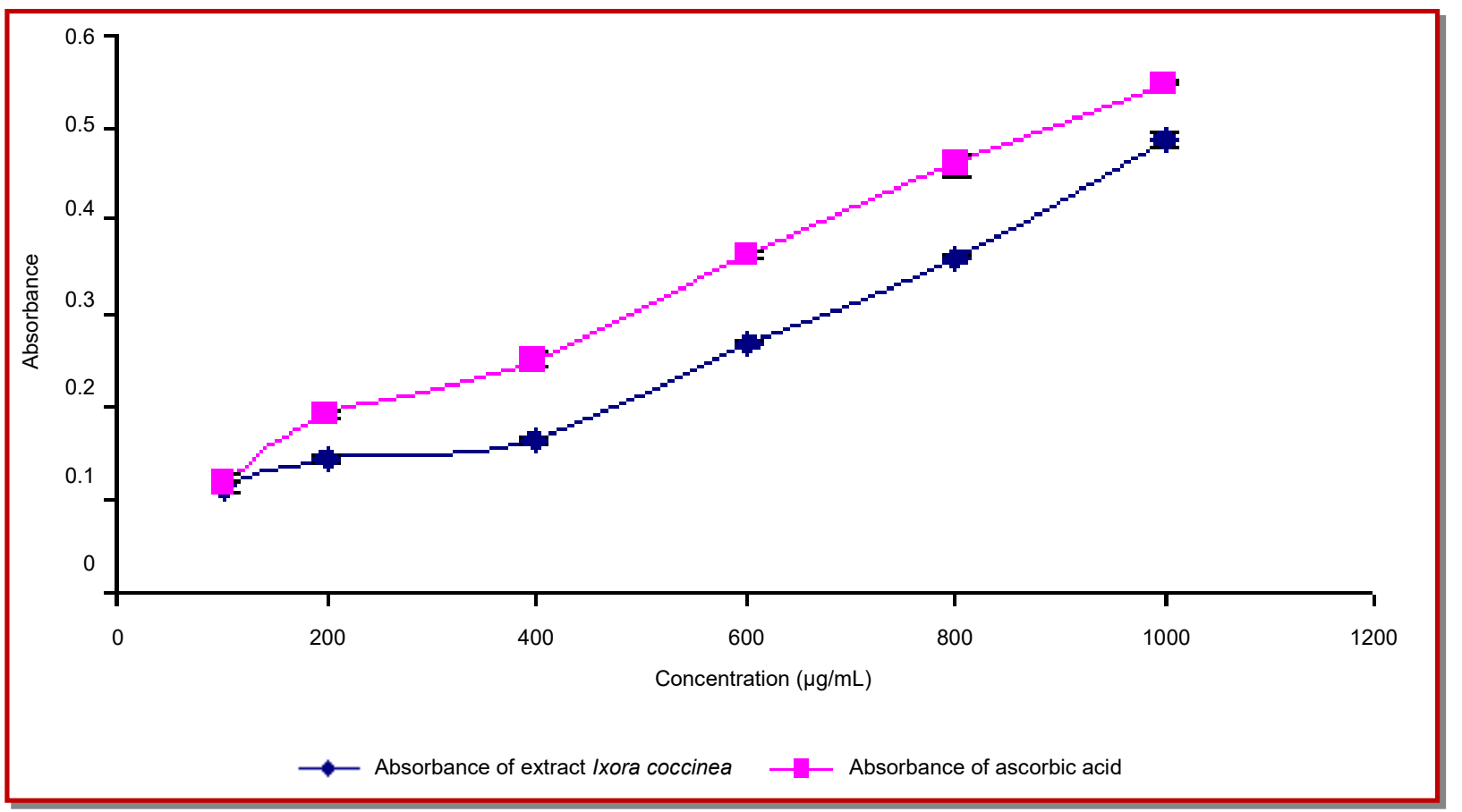

Figure 2: Reducing power of the leaves of Ixora coccinea extract compared to ascorbic acid. Values are the average of duplicate experiments and represented as mean \pm standard deviation

The plant extract could reduce the most $\mathrm{Fe}^{3+}$ ions, which had a lesser reductive activity than the reference standard of ascorbic acid.

Total antioxidant capacity of the methanol extract is given in Figure 3. Total antioxidant capacity of $I$. coccinea is expressed as the number of equivalents of ascorbic acid. The phosphomolybdenum method was based on the reduction of Mo (VI) to Mo (V) by the anti -oxidant compound and the formation of a green phosphate/Mo (V) complex with a maximal absorption at $695 \mathrm{~nm}$. The assay is successfully used to quantify 


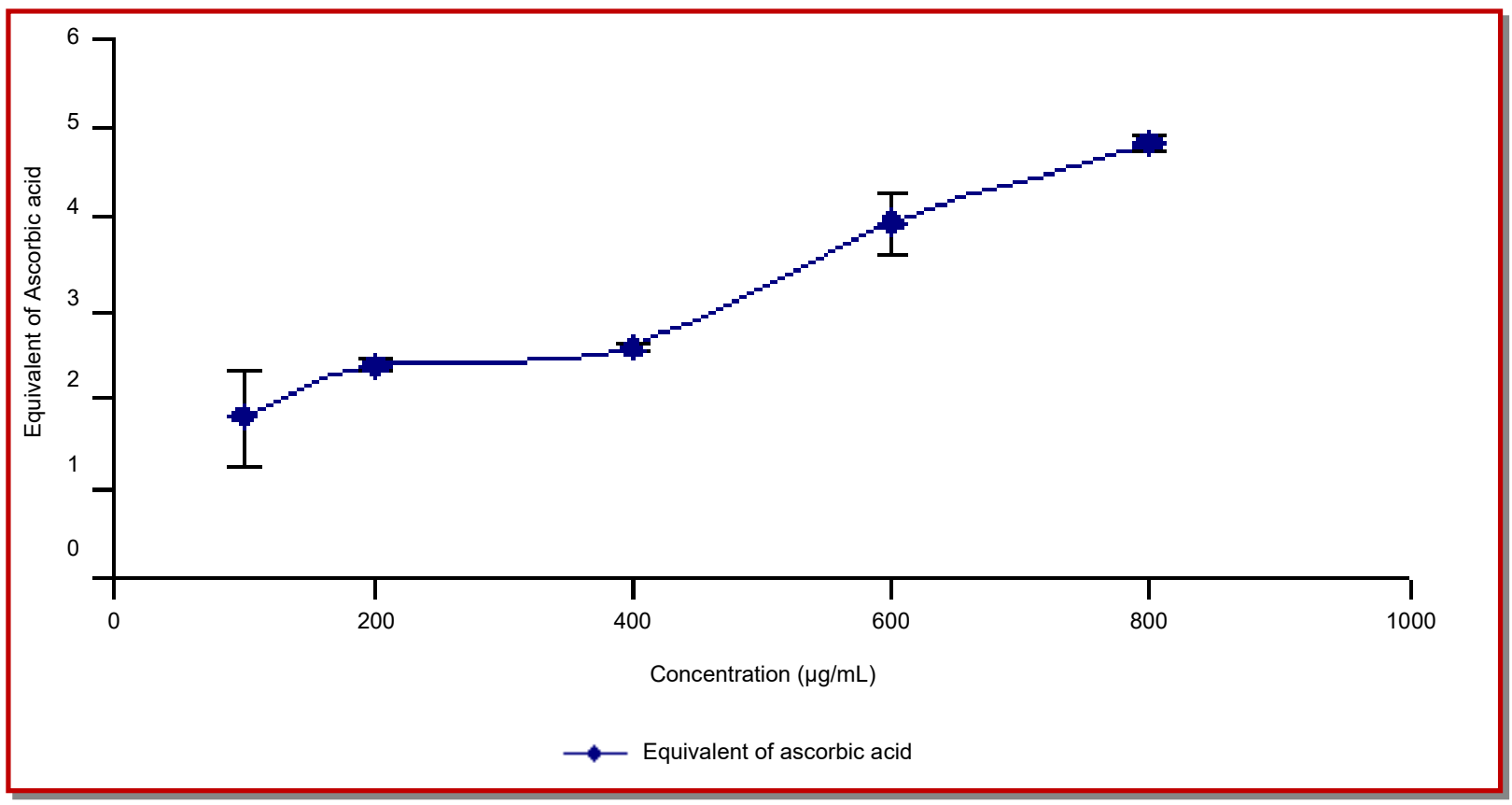

Figure 3: Total antioxidant capacity of the flowers of Ixora coccinea extracts. Value s are the average of duplicate experiments and represented as mean \pm standard deviation

vitamin $\mathrm{E}$ in seeds and, being simple and independent of other antioxidant measurements commonly employed, it was decided to extend its application to plant extracts (Prieto et al., 1999). Moreover, it is a quantitative one, since the antioxidant activity is expressed as the number of equivalents of ascorbic acid. The study reveals that the antioxidant activity of the extract exhibits increasing trend with the increasing concentration of the plant extract.

This in vitro antioxidant activity of the methanol extract is further supported by other workers who reported that the extract of $I$. coccinea significantly protect the experimental animal during cis platin- and cyclophosphamide-induced toxicity (Latha and Panikkar, 2001; Latha and Panikkar, 1999).

\section{Conclusion}

It can be concluded that the methanol extract of $I$. coccinea possesses the antioxidant substances which may be potentially responsible for its antiinflammatory and chemoprotective mechanism as well as using this plant's extract as folkloric remedies.

\section{Financial Support}

Self-funded

\section{Ethical Issue}

The study was approved by the Ethical Committee of the Stamford University Bangladesh

\section{Conflict of Interest}

Author declares no conflict of interest

\section{References}

Alam MA, Nyeem MAB, Awal MA, Mostofa M, Alam MS, Subhan N, Rahman MM. Anti-oxidant and hepatoprotective action of the crude methanolic extract of the flowering top of Rosa damascena. OPEM. 2008; 8: 164-70.

Alam MA, Ghani A, Subhan N, Rahman MM, Haque MS, Majumder MM, Mazumder MEH, Akter RA, Nahar L, Sarker SD. Anti-oxidant and membrane stabilizing properties of the flowering tops of Anthocephalus cadamba. Nat Pro Commun. 2008; 3: 65-67.

Annapurna J, Amarnath PVS, Amar Kumar D, Ramakrishna SV, Raghavan KV. Antimicrobial activity of Ixora coccinea leaves. Fitoterapia 2003; 74: 291-93. http:// dx.doi.org/10.1016/S0367-326X(03)00037-6

\section{PMid:12727497}

Boynes JW. Role of oxidative stress in the development of complication in diabetes. Diabetes 1991; 40: 405-11. http:// dx.doi.org/10.2337/diabetes.40.4.405

\section{PMid:2010041}

Braca A, Sortino C, Politi M, Morelli I, Mendez J. Anti-oxidant activity of flavonoids from Licania licaniaeflora. J Ethnopharmacol. 2002; 79: 379-81. http://dx.doi.org/ 10.1016/S0378-8741(01)00413-5

\section{PMid:11849846}

Branen AL. Toxicology and biochemistry of butylated 
hydroxyanisole and butylated hydroxytoluene. J Am Oil Chem Soc. 1975; 52: 59-63. http://dx.doi.org/ 10.1007/ BF02901825

\section{PMid:805808}

Collier A, Wilson R, Bradley H, Thomson JA, Small M. Free radical activity in type 2 diabetes. Diabetes 1990; 7: 27-30.

Duh PD, Tu YY, Yen GC. Antioxidant activity of water extract of Harng Jyur (Chrysanthemum moifolium Ramat). LebensmWiss Technol. 1999; 32: 269-77.

Fernandez MA, De las Heras B, Garcia MD, Saenz MT, Villar A. New insights into the mechanism of action of the antiinflammatory Triterpene lupeole. J Pharm Pharmacol. 2001; 53: 1533-39. http://dx.doi.org/10.1211/ 0022357011777909

\section{PMid:11732756}

Ghani A. Medicinal plants of Bangladesh with chemical constituents and uses. Dhaka, The Asiatic Society of Bangladesh, 2003, p 267.

Gordon MH. The mechanism of the antioxidant action in vitro. In: Food antioxidants. Hudson BJF (ed.). London, Elsevier, 1990, pp 1-18.

Gyamfi MA, Aniya Y. Antioxidant properties of thonningianin A, isolated from the African medicinal herb, Thonningia sanguine. Biochem Pharmacol. 2002; 63: 1725-37. http:// dx.doi.org/10.1016/S0006-2952(02)00915-2

\section{PMid:12007576}

Hasan MS, Ahmed MI, Mondal S, Uddin SJ, Masud MM, Sadhu SK, Ishibashi M. Antioxidant, antinociceptive activity and general toxicity study of Dendrophthoe falcata and isolation of quercitrin as the major component. OPEM. 2006; 6: 355-60.

Ismaili H, Sosa S, Brkic D, Fkih-Tetouani S, IIidrrissi A, Touati D, Aquino RP, Tubaro A. Topical anti-inflammatory activity of extracts and compounds from Thymus broussonettii. J Pharm Pharmacol. 2002; 54: 1137-40. http:// dx.doi.org/10.1211/ 002235702320266316

PMid:12195830

Ito N, Fukushima S, Hasegawa A, Shibata M, Ogiso T. Carcinogenicity of butylated anisole in F344 rats. J Natl Cancer Inst. 1983; 70: 343-47.

Jorgensen LV, Madsen HL, Thomsen MK, Dragsted LO, Skibsted LH. Regulation of phenolic antioxidants from phenoxyl radicals: An ESR and electrochemical study of anti-oxidant hierarchy. Free Radical Res. 1999; 30: 207-20. http:/ /dx.doi.org/10.1080/10715769900300231

\section{PMid:10711791}

Kayano S, Kikuzaki H, Fukutsuka N, Mitani T, Nakatani N. Antioxidant activity of prune (Prunus domestica L.) constituents and a new synergist. J Agric Food Chem. 2002; 50: 3708-12. http://dx.doi.org/10.1021/jf0200164

PMid:12059147
Latha PG, Panikkar KR. Chemoprotective effect of Ixora coccinea L. flowers on cisplatin induced toxicity in mice. Phytother Res. 2001; 15: 364-66. http:/ / dx.doi.org/ 10.1002/ ptr.727

\section{PMid:11406864}

Latha PG, Panikkar KR, Modulatory effects of Ixora coccinea flower on cyclophosphamide-induced toxicity in mice. Phytother Res. 1999; 13: 517-20. http://dx.doi.org/10.1002/(SICI)1099-1573(199909)13:6\% 3c517::AID-PTR524\%3e3.0.CO;2-Y

PMid:10479765

Latha PG, Panikkar KR. Cytotoxic and antitumor principles from Ixora coccinea flowers. Cancer Lett. 1998; 130: 197-202. http://dx.doi.org/10.1016/S0304-3835(98)00140-2

\section{PMid:9751274}

Lim SN, Cheung PCK, Ooi VEC, Ang PO. Evaluation of antioxidative activity of extracts from a brown seaweed, Sargassum siliquastrum. J Agric Food Chem. 2002; 50: 386266. http://dx.doi.org/ 10.1021/jf020096b

\section{PMid:12059172}

Oyaizu M. Studies on product of browning reaction prepared from glucose amine. Jap J Nutr. 1986; 44: 307-15.

Patocka J. Biologically active pentacyclic triterpenes and their current medicine signification. J Appl Biomed. 2003; 1: 7-12.

Prieto P, Pineda M, Aguilar M. Spectrophotometric quantitation of antioxidant capacity through the formation of a phosphomolybdenum complex: Specific application to the determination of vitamin E. Anal Biochem. 1999; 269: 337-41. http:// dx.doi.org/ 10.1006/abio.1999.4019

\section{PMid:10222007}

Ragasa CY, Tiu F, Rideout JA. New cycloartenol esters from Ixora coccinea. Nat Prod Res. 2004; 18: 319-23. http:// dx.doi.org/10.1080/ 14786410310001630519

\section{PMid:15214483}

Ratnasooriya WD, Deraniyagala SA, Bathige SD, Goonasekara CL, Jayakody JR. Antinociceptive action of aqueous extract of the leaves of Ixora coccinea. Acta Biol Hung. 2005; 56: 21-34. http://dx.doi.org/10.1556/ABiol.56.2005.1-2.3

\section{PMid:15813211}

Ratnasooriya WD, Deraniyagala SA, Galhena G, Liyanage SSP, Bathige SDNK, Jayakody JRAC. Anti-inflammatory activity of the aqueous leaf extract of Ixora coccinea. Pharmaceutical Biol. 2005; 43: 147-52. http://dx.doi.org/10.1080/ 13880200590919483

Repetto MG, Llesuy SF. Antioxidant properties of natural compounds used in popular medicine for gastric ulcers. Braz J Med Biol Res. 2002, 35: 523-34. http:// dx.doi.org/10.1590/S0100-879X2002000500003

PMid:12011936 
Rice-Evans C, Sampson J, Bramley PM, Holloway DE. Why do we expect carotenoids to be antioxidants in vivo? Free Radical Res. 1997; 26: 381-98. http:// dx.doi.org/10.3109/10715769709097818

PMid:9167943

Sabu MC, Kuttan R. Antidiabetic activity of medicinal plants and its relationship with their antioxidant property. J Ethnopharmacol. 2002; 81: 155-60. http:// dx.doi.org/10.1016/S0378-8741(02)00034-X

\section{PMid:12065146}

Trease GE, Evans WC. Pharmacognosy, 12th ed. London, Baillieere Tindal, 1983.

Viturro C, Molina A. Schmeda-Hischmann G. Free radical scavengers from Mutisia friesiana (Asteraceae) and Sanicula graveolens (Apiaceae). Phytother Res. 1999; 13: 422-24. http://dx.doi.org/ 10.1002/(SICI)1099-1573(199908/09) 13:5\%3c422::AID-PTR462\%3e3.0.CO;2-M

PMid:10441784 